\title{
Zircon halogen geochemistry: Insights into Hadean-Archean fluids
}

\author{
H. Tang ${ }^{1 *}$, D. Trail ${ }^{1,2}$, E.A. Bell1, T.M. Harrison ${ }^{1}$
}

Abstract

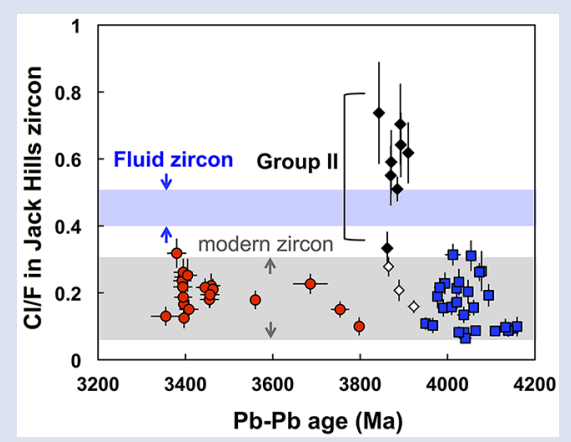

Understanding the distribution of halogens in rocks can potentially trace ancient lithosphere, hydrosphere, and atmosphere interactions. Although no sedimentary rocks older than $3.8 \mathrm{Ga}$ are known, insights into sediment-atmosphere exchange on early Earth could be obtained from knowledge of halogen contents in ancient zircons. Here we present the first study of halogen abundances in Jack Hills zircons together with younger zircons of known provenance to provide geologic context. The relatively low (ca. 0.1-0.6 $\mu \mathrm{g} / \mathrm{g}$ ) chlorine concentrations in most Hadean and Archean Jack Hills zircons are similar to the average concentration in younger igneous zircons. In contrast, significant $\mathrm{Cl}$ enrichments are found in a subset of $\mathrm{ca} .3 .9-3.8 \mathrm{Ga}$ zircons $\left([\mathrm{Cl}]_{\text {average }}=1.43 \pm 0.27 \mu \mathrm{g} / \mathrm{g}\right)$ that appear to record halogen transport under hydrothermal conditions. Such $\mathrm{Cl}$-bearing fluids in early Earth history may reflect extraction of halogens from the interior to near surface environments.

Received 21 September 2018 | Accepted 20 January 2019 | Published 19 February 2019

\section{Introduction}

Earliest Earth remains one of the great frontiers for fundamental discovery as little is known about key events such as the mechanisms and timing of life's origin. Given that $>3.8 \mathrm{Ga}$ rocks are exceedingly rare and no rock older than $4.03 \mathrm{Ga}$ is known (cf. O'Neil et al., 2008), constraining conditions on early Earth has largely relied on the only materials identified from the Hadean eon: 4.4 to 3.8 Ga detrital zircons (Mojzsis et al., 2001; Peck et al., 2001; Harrison et al., 2008; Holden et al., 2009; Bell et al., 2011). Oxygen isotopes, rare earth element (REE) patterns, crystallisation temperatures, and inclusions in detrital zircons from the Jack Hills, Western Australia, are suggestive of the presence of recycled crustal material that had interacted with liquid water at low temperature (e.g., Watson and Harrison, 2005; Trail et al., 2011; Bell and Harrison 2013; Harrison et al., 2017) and show how experimental calibrations can permit zircon to act as an environmental monitor of lithosphere and surface processes. On the other hand, the lack of a known sedimentary record older than $3.83 \mathrm{Ga}$ (Manning et al., 2006) limits our understanding of the volatile evolution on earliest Earth. To address this issue, one approach is to trace those volatile components that partition at measureable levels into zircon. Previous investigations of oxygen isotopes and trace elements in Jack Hills zircons (e.g., Mojzsis et al., 2001; Cavosie et al., 2005; Trail et al., 2007; Bell et al., 2011) indicate two distinctive protolith sources: Group I and Group II (Bell and Harrison, 2013). Group I is similar in most respects to $>3.9 \mathrm{Ga}$ and $<3.8 \mathrm{Ga}$ Jack Hills zircons, with magmatic Th/U and average Ti-in-zircon temperatures ca. $680^{\circ} \mathrm{C}$. Group II is a distinctive subset of the zircons with ages 3.9-3.8 Ga that show distinctive chemistry relative to Group I (lower Th/U, P, and Ce; higher U and Hf). Their Ti-inzircon temperatures are mostly subsolidus, and these zircons are either dark and homogeneous in cathodoluminescence or display patchy zoning. The Group II characteristics imply recrystallisation during thermal events (Hoskin and Black, 2000). Such episodes may have provided a mechanism for volatile transport in early fluids. Given the significance of halogens in lithosphere-hydrosphere-atmosphere interactions, we focus here on their abundances in Jack Hills zircons and examine fractionations between nominally mobile $(\mathrm{Cl})$ and immobile (F) halogens in a variety of reservoirs (e.g., magmatic and metamorphic systems).

\section{Samples and Methods}

Our Jack Hills zircon suite ranges in $\mathrm{U}-\mathrm{Pb}$ age from 4.2 to 3.4 Ga (Table S-2). Oxygen isotope ratios and REE patterns in some of these zircons have been investigated previously and shown to lack secondary alteration (Table S-2, S-3, and S-4, Fig. S-7 and S-8; Bell et al., 2011, 2014, 2016; Bell and Harrison, 2013). Given the possible felsic parent sources of Jack Hills zircon (Bell et al., 2018), zircons from igneous (I-type) and sedimentary (S-type) granitoids from the Phanerozoic Lachlan Fold Belt (LFB), Australia, and Mesozoic batholiths of southern California, USA, were also investigated as

1. Department of Earth, Planetary and Space Sciences, University of California, Los Angeles, Los Angeles CA, 90095 USA

2. Department of Earth and Environmental Sciences, University of Rochester, Rochester, NY, 14618 USA

* Corresponding author (email: haolantang@ucla.edu) 
analogues for establishing geologic provenance. Detection limits $([\mathrm{F}]=0.78 \pm 0.07 \mu \mathrm{g} / \mathrm{g}$ and $[\mathrm{Cl}]=0.12 \pm 0.02 \mu \mathrm{g} / \mathrm{g}$ with 2 se.; Fig. S-4) were determined by analysing synthetic zircons grown in halogen-free conditions by the 1 atm flux method (e.g., Trail et al., 2016). We also synthesised zircon grains in a halogen-rich fluid to explore $\mathrm{Cl}$ (and F) partitioning in zircon and to produce an analogue of recrystallised zircon (see Supplementary Information for experimental details).

The in situ analyses of $\mathrm{Cl}$ and $\mathrm{F}$ in zircon were performed using the CAMECA ims1290 ion microprobe. Analytical details are described in the Supplementary Information. Mud Tank zircons implanted with known $\mathrm{F}$ or $\mathrm{Cl}$ isotopic dosages were analysed as concentration standards. Cracks/inclusions in samples were identified via secondary and backscattered electron SEM imaging. Analysis zones were limited to regions without cracks or inclusions.

\section{Results}

Young zircons (1.1-0.1 Ga) display uniform F concentrations (Fig. 1) within uncertainty $(1.80 \pm 0.11 \mu \mathrm{g} / \mathrm{g})$, except AS3 zircon (Duluth Complex, Minnesota), which we attribute to enrichment during hydrothermal alteration (Takehara et al., 2018). All the post-Archean zircons in this study exhibit systematically low $\mathrm{Cl}$ contents, some of which cannot be resolved from the baseline. The average concentration is determined as $0.31 \pm 0.04 \mu \mathrm{g} / \mathrm{g}$.

Fluorine concentrations in all 58 Jack Hills samples are slightly higher than those in zircons from the LFB and southern Californian granitoids $(2.28 \pm 0.19 \mu \mathrm{g} / \mathrm{g})$. Chlorine concentrations and $\mathrm{Cl} / \mathrm{F}$ ratios in Jack Hills zircons appear to vary with age (Fig. 1). Significantly high $\mathrm{Cl}$ concentration $\left([\mathrm{Cl}]_{\text {average }}=1.19 \pm 0.32 \mu \mathrm{g} / \mathrm{g}\right)$ is observed in a subset of zircons within a narrow age range of 3.9-3.8 Ga. Archean grains with ages from 3.8 to $3.4 \mathrm{Ga}$ display $\mathrm{Cl}$ contents identical to the young zircons $\left([\mathrm{Cl}]_{\text {average }}=0.34 \pm 0.04 \mu \mathrm{g} / \mathrm{g}\right)$, pointing to a magmatic environment with halogens levels roughly similar to modern igneous systems. Two Jack Hills zircons older than 3.9 Ga yield exceptionally high $\mathrm{Cl}$ contents (RSES 178-7.14 and RSES 178-8.8 with $\mathrm{Pb}-\mathrm{Pb}$ ages of $4012 \mathrm{Ma}$ and $4073 \mathrm{Ma}$, respectively), although the halogen measurements on the other 25 grains are within error of the range of $0.1-0.6 \mu \mathrm{g} / \mathrm{g}$ in the young zircons.

\section{Halogens in Jack Hills Zircons: Primary or Secondary?}

Given that mobile elements can be substituted into the zircon lattice during secondary alteration (e.g., Bell et al., 2016), care must be taken to ascertain that $\mathrm{Cl}$ and $\mathrm{F}$ concentrations reported for Jack Hills zircons do not represent post-crystallisation hydrothermal alteration. In our study, $\mathrm{U}-\mathrm{Pb}$ ages in all $\mathrm{Cl}$-rich zircons are concordant within $\pm 10 \%$ (Bell and Harrison, 2013) indicating little $\mathrm{Pb}$ loss or $\mathrm{U}$ gain after $3.8 \mathrm{Ga}$. In addition, two indices, including $(\mathrm{Sm} / \mathrm{La})_{\mathrm{N}}$ (Hoskin, 2005) and the LREE-I $[=(\mathrm{Dy} / \mathrm{Nd})+(\mathrm{Dy} / \mathrm{Sm})$; Bell et al., 2016], can test for possible alteration effects leading to crystalline degeneration. The high values of both indices for all grains (except one Archean zircon) are indicative of crystalline zircon, including the $\mathrm{Cl}$-rich grains (see Bell et al., 2016) (Fig. 2). The halogen abundances are interpreted as reflecting concentrations present during crystallisation from their primary sources magmas. The distribution of oxygen isotopes in our samples $\left(\delta^{18} \mathrm{O}_{\mathrm{ave}}=5.87 \pm 0.17\right.$; Fig. S-7 $)$ is consistent with the prevailing populations for their corresponding time periods (Cavosie et al., 2005; Trail et al., 2007; Bell et al., 2016) and no obvious correlation between $\delta^{18} \mathrm{O}$ and $\mathrm{Cl}$ concentration is observed. The prominent excursion of $\mathrm{Cl}$ content in multiple 3.9-3.8 Ga zircons is higher than that seen thus far in post-Archean grains.
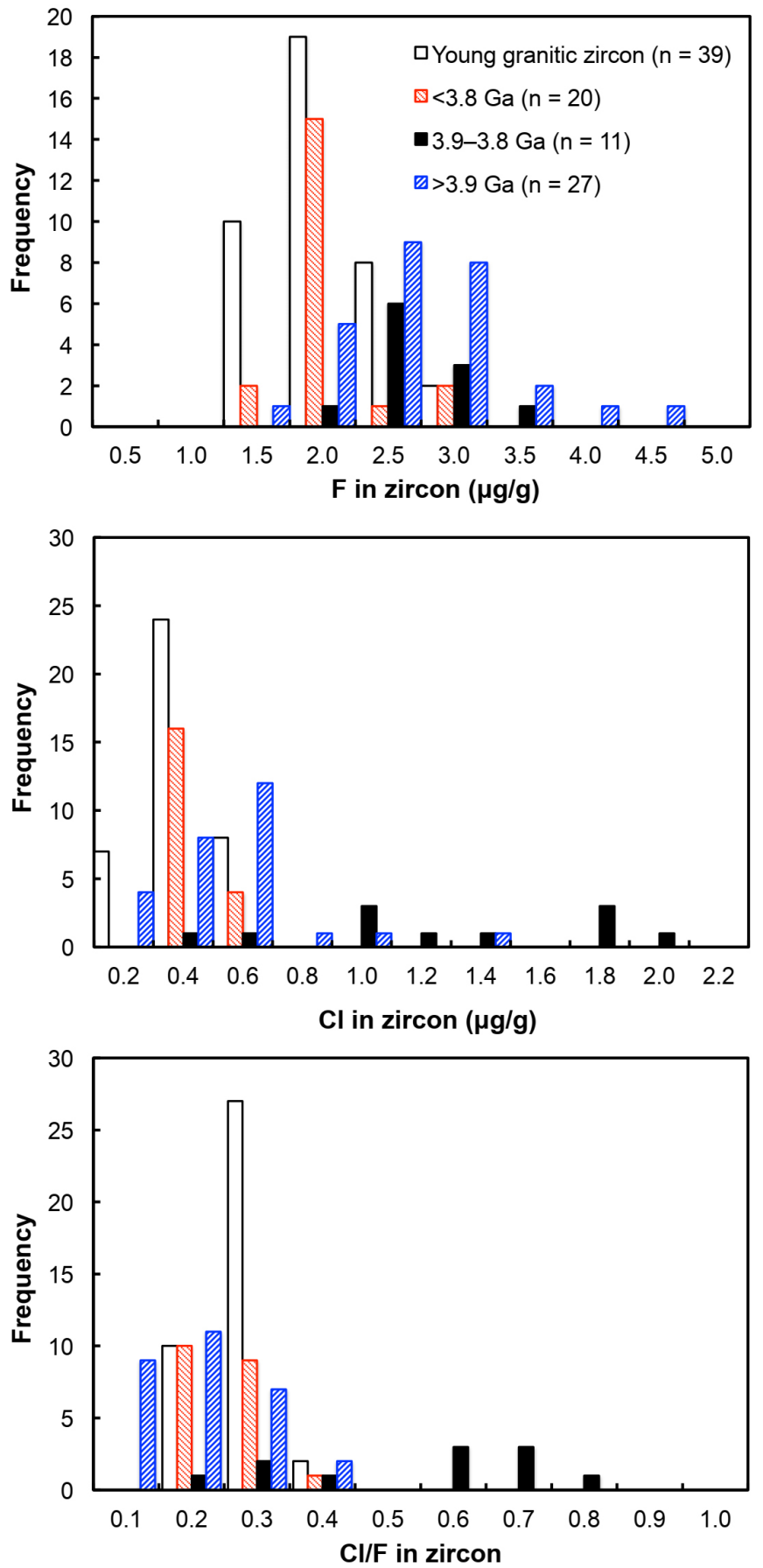

Figure 1 Fluorine concentrations in Jack Hills zircons ([F] average $=2.28 \pm 0.19 \mu \mathrm{g} / \mathrm{g}$ ) are generally indistinguishable from those in young granitic zircons $\left([\mathrm{F}]_{\text {average }}=1.80 \pm 0.11 \mu \mathrm{g} / \mathrm{g}\right.$ ). Elevated $\mathrm{Cl}$ concentrations observed in eight 3.9-3.8 Ga zircons (black columns) yield distinctly high $\mathrm{Cl} / \mathrm{F}$ ratios $(\mathrm{Cl} / \mathrm{F}>0.3)$ when compared with other Jack Hills zircons. 


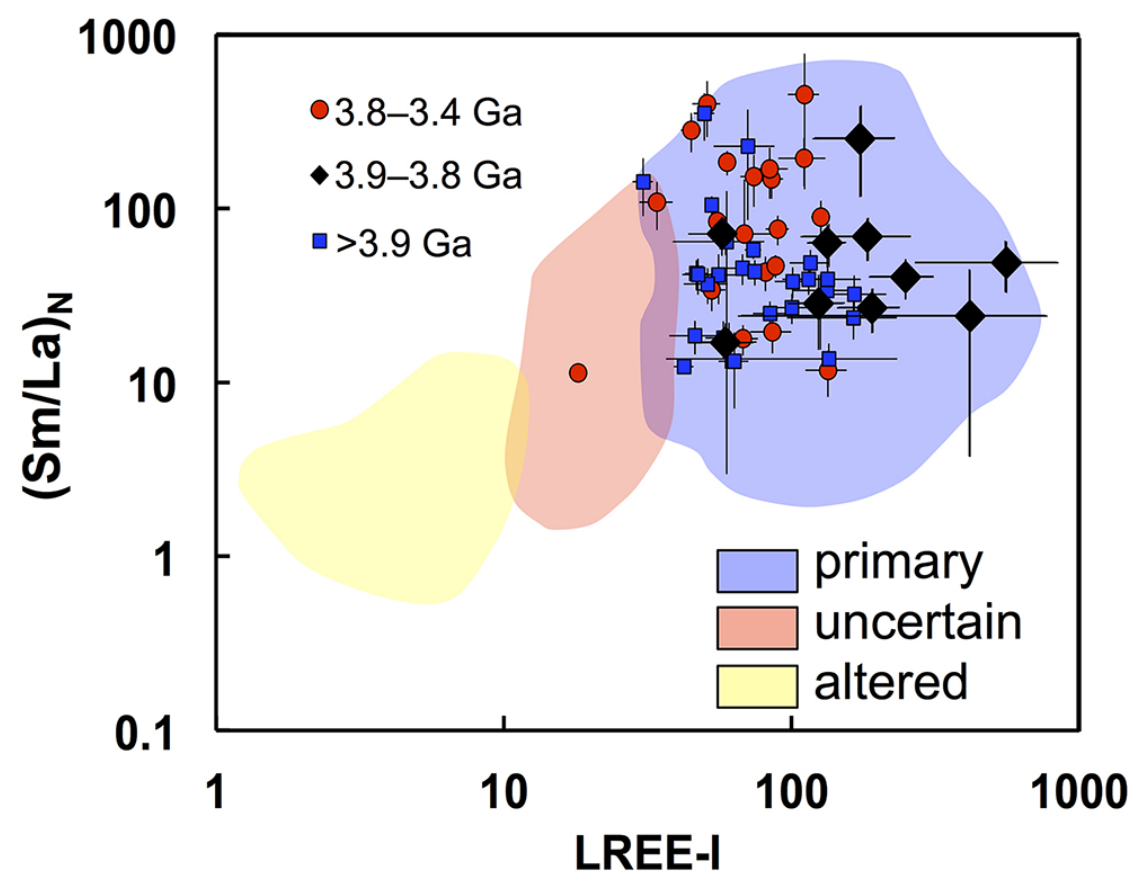

Figure 2 High values of $(\mathrm{Sm} / \mathrm{La})_{\mathrm{N}}$ and LREE-I $[(\mathrm{Dy} / \mathrm{Nd})+(\mathrm{Dy} / \mathrm{Sm})]$ in Jack Hills sample grains imply that most of samples, especially $\mathrm{Cl}$-rich zircons, are primary. The elevated $\mathrm{Cl}$ concentrations in zircons therefore derived from primary sources.

\section{Group II Zircons: Recrystallisation in Cl-rich Fluids?}

Bell and Harrison (2013) classified 3.9-3.8 Ga Jack Hills zircon grains into two categories. Group I exhibits temperatures and compositions similar to other igneous zircons across the age spectrum, and Group II shows high U, lower (Th/U) ratio $(<0.25)$, and anomalously low Ti $(1.82 \pm 0.47 \mu \mathrm{g} / \mathrm{g})$. The concordant $\mathrm{U}-\mathrm{Pb}$ ages in Group II zircons and their igneous protolith similar to Group I suggest that they formed by transgressive recrystallisation, in which recrystallisation occurs across the entire zircon under high temperatures (Hoskin and Black, 2000). The distribution of halogens in the Jack Hills zircons is consistent with this classification. The ca. 3.9 Ga zircons in this study contain three Group I zircons $\left([\mathrm{Cl}]_{\text {average }}=0.58 \pm 0.28 \mu \mathrm{g} / \mathrm{g}\right)$ and eight Group II zircons $\left([\mathrm{Cl}]_{\text {average }}=1.43 \pm 0.33 \mu \mathrm{g} / \mathrm{g}\right)($ Table S-2), in which two Group I zircons (RSES 56-3.17 and RSES 181-2.10) display Cl contents identical to the young zircons, and the other Group I zircon (RSES 178-20.20) has a $\mathrm{Cl}$ concentration higher than the young zircons, but consistent with the lowest level of $\mathrm{Cl}$ contents in Group II zircons (Fig. 3a).

Significant differences in $\mathrm{Cl} / \mathrm{F}$ ratios are observed between Group I zircons and Group II zircons (Fig. 3b). The Jack Hills zircons with the age of 3.8-3.3 Ga and 4.2-3.9 Ga display $\mathrm{Cl} / \mathrm{F}$ ratios within the range of young magmatic zircons (0.02-0.30). In addition, in the period of 3.9-3.8 Ga, no distinguishable difference of $\mathrm{Cl} / \mathrm{F}$ ratios in three Group I zircons are found compared to other Jack Hills zircons. However, $\mathrm{Cl} / \mathrm{F}$ ratios of Group II zircons are distinctively higher (0.33-0.74) than the ratios of young magmatic zircons.

The Ti-in-zircon crystallisation temperatures $\left(\mathrm{T}^{\mathrm{x} l \mathrm{n}}\right)$ of each Jack Hills zircon are obtained using a protocol developed in previous studies (Watson and Harrison, 2005; Harrison et al., 2008). As shown in Figure 4, the Jack Hills samples group into two clusters based on their $\mathrm{T}^{\text {xlln }}$ and $\mathrm{Cl} / \mathrm{F}$ ratios. All the Cl-rich Group II zircons exhibit distinct $\mathrm{T}^{\mathrm{x} l \mathrm{ln}}$ below the nominal granite solidus $\left(\sim 650^{\circ} \mathrm{C}\right)$, with an average Txlln of $596 \pm 17^{\circ} \mathrm{C}$. In contrast, the $\mathrm{T}^{\mathrm{xlln}}$ among all other Jack Hills zircons with low $\mathrm{Cl} / \mathrm{F}$ ratios overall cluster about an identical average of 680
${ }^{\circ} \mathrm{C}$, indistinguishable from the Hadean distribution (Watson and Harrison, 2005).

A possible mechanism to interpret the low Ti contents and other characteristics of Group II zircons is metamorphic transgressive recrystallisation of originally igneous zircons (Bell and Harrison, 2013). High temperature transgressive recrystallisation results in flushing the more incompatible trace elements (e.g., Ce) from the mineral, an increase in compatible elements (e.g., Hf, U), and homogeneous dark textures (Hoskin and Black, 2000). These characteristics are all consistent with the chemistry and internal structure of Group II zircons. Moreover, transgressive recrystallisation of zircon occurs during metamorphism at temperatures up to $600{ }^{\circ} \mathrm{C}$. Such conditions can be achieved by the presence of hydrothermal fluids which can quickly elevate and maintain local temperatures for significant durations (Hoskin and Black, 2000). Zircon recrystallisation can occur in the contact or absence of fluids, although the elevated $\mathrm{Cl}$ concentrations and $\mathrm{Cl} / \mathrm{F}$ ratios in Group II Jack Hills zircons relative to magmatic zircons strongly suggest the involvement of $\mathrm{Cl}$-rich fluids at ca. $3.9 \mathrm{Ga}$, which would additionally enhance zircon recrystallisation given high solubility of $\mathrm{ZrO}_{2}$ in saline fluids relative to pure $\mathrm{H}_{2} \mathrm{O}$ (Bernini et al., 2013).

We can roughly estimate $\mathrm{Cl}$ content in fluids during Group II recrystallisation based on the analysis of synthetic zircon synthesised in a Cl- and F-bearing aqueous fluid. The zircon synthesised from a fluid with $4000 \mu \mathrm{g} / \mathrm{g} \mathrm{Cl}$ and $2000 \mu \mathrm{g} / \mathrm{g}$ F displays a Cl concentration of $\sim 1 \mu \mathrm{g} / \mathrm{g}$ and a $\mathrm{Cl} / \mathrm{F}$ ratio of 0.46 , demonstrating that $\mathrm{Cl}$ can substitute into zircon when crystallising in fluid-rock systems (Table S-1). The $\mathrm{Cl} / \mathrm{F}$ ratio is relatively low compared with ratios in Group II zircons, which could be attributed to the high temperature $\left(1300{ }^{\circ} \mathrm{C} ; 1\right.$ $\mathrm{GPa})$ of the experiment relative to Hadean conditions $\left(\sim 680^{\circ} \mathrm{C}\right)$ and/or the different $\mathrm{Cl} / \mathrm{F}$ ratios compared to the natural fluid ratios. The partition coefficient $\left(\mathrm{D}_{\text {zircon-fluid }}\right)$ of $2.3 \pm 0.2 \times 10^{-4}$ implies fluids with $\mathrm{Cl}$ contents of $4 \times 10^{3}-1 \times 10^{4} \mu \mathrm{g} / \mathrm{g}$ during Group II recrystallisation. This is similar to $\mathrm{Cl}$ concentrations in some brine hydrothermal fluids in the present day (e.g., Stefánsson and Barnes, 2016), though significantly lower than that in modern deep crustal fluids (e.g., Bodnar, 2003). Future systematic experiments are required for precise estimates on $\mathrm{D}_{\text {zircon-fluid }}$ under different P-T conditions. 

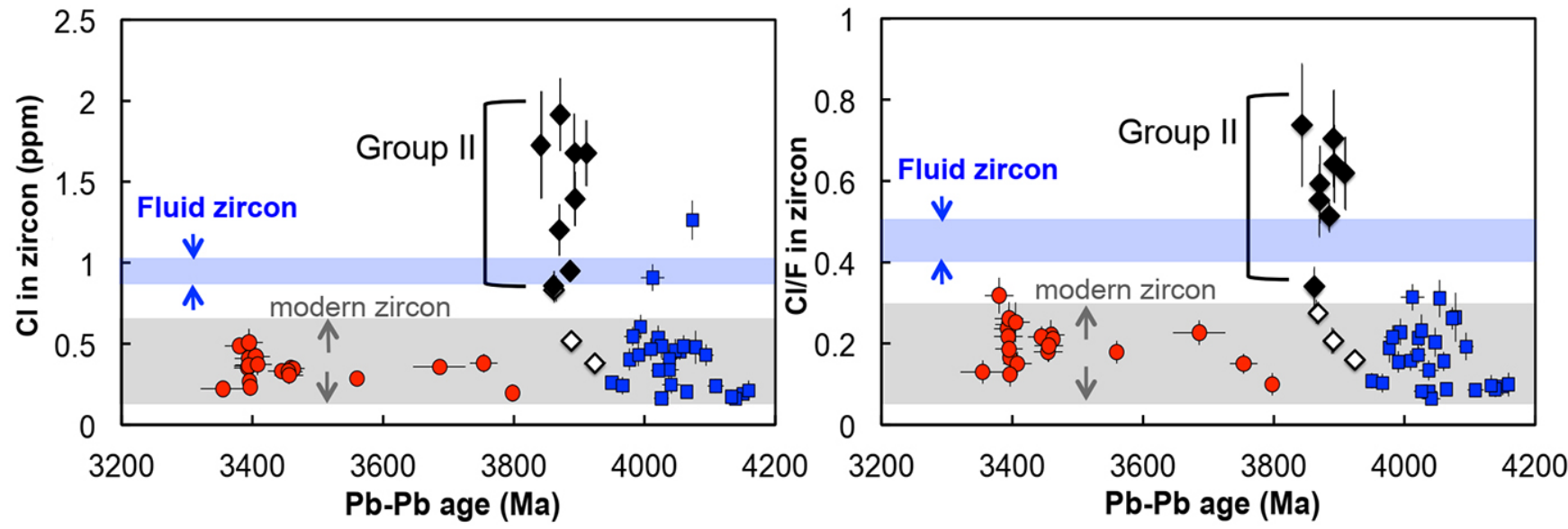

Figure 3 (a) Chlorine distribution and (b) $\mathrm{Cl} / \mathrm{F}$ fractionation in Jack Hills zircons are mainly identical to the ranges determined from modern magmatic zircons in this study (red circles: <3.8 Ga zircons; white diamonds: 3.9-3.8 Ga Group I zircons; blue rectangles: >3.9 Ga zircons; grey bar: modern zircon ranges) except Group II zircons crystallised at 3.9-3.8 Ga (black diamonds). A synthetic zircon grown in an aqueous-rich fluid exhibits $\mathrm{Cl}$ content and $\mathrm{Cl} / \mathrm{F}$ ratios (blue bars) that fall within the range of Group II.

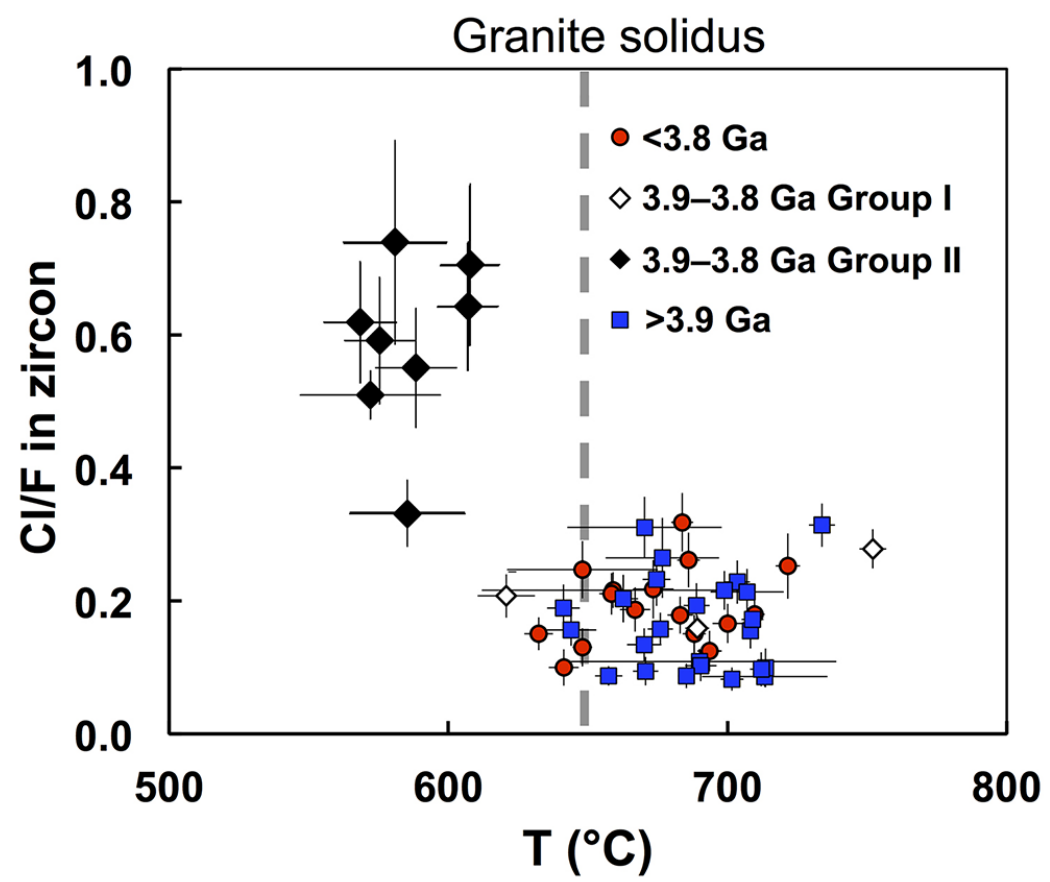

Figure 4 Chlorine-rich Group II zircons are characterised by Ti-in-zircon temperatures below granite solidus. The clearly distinguished cluster of Group II from other magmatic zircons suggests the mechanism of Group II as solid state recrystallisation involving Cl-bearing fluids.

\section{Implications and Conclusions}

Studies of Bulk Silicate Earth (BSE) halogen abundances suggest the anomalous depletions observed in volatile halogens $(\mathrm{Cl}, \mathrm{Br}$, and I) relates to their volatility during condensation from the solar nebula (Lodders, 2003; Sharp and Draper, 2013). However, these putative depletions were rendered moot by a recent analysis of the abundances of $\mathrm{Cl}, \mathrm{Br}$, and I in meteorites, which indicate much lower average abundances in primitive chondrites (Clay et al., 2017) than previously thought. Given the large proportion of heavy halogens in the crustal reservoirs (80-90\% of BSE; Burgess et al., 2002), notwithstanding contributions from a late veneer (ca. $1 \%$ Earth mass) or complete mantle degassing (maximum estimated extraction efficiency is $50 \%$; Allègre et al., 1996), additional halogens transported from deep Earth would still be required, likely via early fluids.
The enrichment of $\mathrm{Cl}$ in all Group II Jack Hills zircons indicates the presence of fluids with $\mathrm{Cl}$ concentrations similar to modern metamorphic fluids. The average $\delta^{18} \mathrm{O}$ identical to prevailing populations of other Jack Hills zircons suggest that rather than recycled crustal material, which would yield distinctly high $\delta^{18} \mathrm{O}$ values, the $\mathrm{Cl}$-bearing fluids occurred inside of nascent crust, either in the deeper crust or near the surface following impacts. Whether the $\sim 3.9 \mathrm{Ga}$ recrystallisation arises from meteoritic, meteoric or deep sourced fluids, the elevated $\mathrm{Cl}$ concentration in Group II zircons provides the first insight into halogen transfer and cycling through metamorphic fluids on early Earth.

\section{Acknowledgements}

We thank Ming-Chang Liu for assistance with our SIMS analyses and Bruce S. Brunschwig for his assistance with 
the profilometer at the Molecular Materials Research Center, Caltech. Yanling Wang is also thanked for assistance. The ion microprobe facility at UCLA is partially supported by a grant from the Instrumentation and Facilities Program, Division of Earth Sciences, NSF (1339051). The research received support from EAR-1447404. We thank Veronique Le Roux, an anonymous reviewer, and the editor Horst Marschall for helpful reviews that improved the paper.

Editor: Horst R. Marschall

\section{Additional Information}

Supplementary Information accompanies this letter at http:// www.geochemicalperspectivesletters.org/article1905.

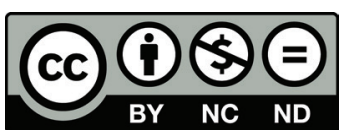

This work is distributed under the Creative Commons Attribution Non-Commercial No-Derivatives 4.0 License, which permits unrestricted distribution provided the original author and source are credited. The material may not be adapted (remixed, transformed or built upon) or used for commercial purposes without written permission from the author. Additional information is available at http://www.geochemicalperspectivesletters.org/ copyright-and-permission $\underline{s}$.

Cite this letter as: Tang, H., Trail, D., Bell, E.A., Harrison, T.M. (2019) Zircon halogen geochemistry: Insights into HadeanArchean fluids. Geochem. Persp. Let. 9, 49-53.

\section{References}

Allègre, C.J., Hofmann, A., O'Nions, K. (1996) The argon constraints on mantle structure. Geophysical Research Letters 23, 3555-3557.

Bell, E.A., Harrison, T.M. (2013) Post-Hadean transitions in Jack Hills zircon provenance: A signal of the Late Heavy Bombardment? Earth and Planetary Science Letters 364, 1-11.

Bell, E.A., Harrison, T.M., McCulloch, M.T., Young, E.D. (2011) Early Archean crustal evolution of the Jack Hills Zircon source terrane inferred from Lu-Hf, ${ }^{207} \mathrm{~Pb} /{ }^{206} \mathrm{~Pb}$, and $\delta^{18} \mathrm{O}$ systematics of Jack Hills zircons. Geochimica et Cosmochimica Acta 75, 4816-4829.

Bell, E.A., Harrison, T.M., KoHL, I.E., YounG, E.D. (2014) Eoarchean crustal evolution of the Jack Hills zircon source and loss of Hadean crust. Geochimica et Cosmochimica Acta 146, 27-42.

Bell, E.A., BoeHnKe, P., HARrison, T.M. (2016) Recovering the primary geochemistry of Jack Hills zircons through quantitative estimates of chemical alteration. Geochimica et Cosmochimica Acta 191, 187-202.

Bell, E.A., Boehnke, P., Harrison, T.M., Wielicki, M.M. (2018) Mineral inclusion assemblage and detrital zircon provenance. Chemical Geology 477, 151-160.

Bernini, D., Audétat, A., Dolejš, D., Keppler. H. (2013) Zircon solubility in aqueous fluids at high temperatures and pressures. Geochimica et Cosmochimica Acta 119, 178-187.

BODNAR, R.J. (2003) Introduction to aqueous fluid systems. In: Samson, I. Anderson, A., Marshall, D. (Eds.) Fluid Inclusions: Analysis and Interpretation. Mineralogical Association of Canada Short Course Series Volume 32, 81-99.

Burgess, R., Layzelle, E., Turner, G., Harris, J.W. (2002) Constraints on the age and halogen composition of mantle fluids in Siberian coated diamonds. Earth and Planetary Science Letters 197, 193-203.

Cavosie, A.J., Valley, J.W., Wilde, S.A. (2005) Magmatic $\delta^{18} \mathrm{O}$ in 4400-3900 Ma detrital zircons: A record of the alteration and recycling of crust in the Early Archean. Earth and Planetary Science Letters 235, 663-681.

Clay, P.L., Burgess, R., Busemann, H., Ruzié-Hamilton, L., JoACHim, B., DAY, J.M.D., BAllentine, C.J. (2017) Halogens in chondritic meteorites and terrestrial accretion. Nature 551, 614-618.

Harrison, T.M., SchmitT, A.K., McCulloch, M.T., Lovera, O.M (2008) Early ( $>4.5 \mathrm{Ga})$ formation of terrestrial crust: Lu-Hf, $\delta^{18} \mathrm{O}$, and Ti thermometry results for Hadean zircons. Earth and Planetary Science Letters 268, 476-486.
HARrison, T.M., Bell, E.A., BoeHnke, P. (2017) Hadean zircon petrochronology. Reviews in Mineralogy and Geochemistry 83, 329-363.

Holden, P., Lanc, P., Ireland, T.R., Harrison, T.M., Foster, J.J. Bruce, Z. (2009) Mass-spectrometric mining of Hadean zircons by automated SHRIMP multi-collector and single-collector $\mathrm{U} / \mathrm{Pb}$ zircon age dating: the first 100,000 grains. International Journal of Mass Spectrometry 286, 53-63.

Hoskin P.W.O. (2005) Trace-element composition of hydrothermal zircon and the alteration of Hadean zircon from the Jack Hills, Australia. Geochimica et Cosmochimica Acta 69, 637-648.

HoskIN, P.W.O., BLACK, L.P. (2000) Metamorphic zircon formation by solidstate recrystallization of protolith igneous zircon. Journal of metamorphic Geology 18, 423-439.

LODDERS, K. (2003) Solar system abundances and condensation temperatures of the elements. The Astrophysical Journal 591, 1220-1247.

Manning, C.E., Mojzsis, S.J., Harrison, T.M. (2006) Geology, age and origin of supracrustal rocks at Akilia, West Greenland. American Journal of Science 306, 303-366.

Mojzsis, S.J., Harrison, T.M., Pidgeon, R.T. (2001) Oxygen-isotope evidence from ancient zircons for liquid water at the Earth's surface 4,300 Myr ago. Nature 409, 178-181.

O’Neil, J., Carlson, R.W., Francis, D., Stevenson, R.K. (2008) Neodymium-142 evidence for Hadean mafic crust. Science 321, 1828-1831.

Peck, W.H., Valley, J.W., Wilde, S.A., Graham, C.M. (2001) Oxygen isotope ratios and rare earth elements in 3.3 to 4.4 Ga zircons: Ion microprobe evidence for high $\delta^{18} \mathrm{O}$ continental crust and oceans in the Early Archean. Geochimica et Cosmochimica Acta 65, 4215-4229.

SHARP, Z.D., DRAPER, D.S. (2013) The chlorine abundance of Earth: implications for a habitable planet. Earth and Planetary Science Letters 369, 71-77.

StefÁnsSON, A., BARNES, J.D. (2016) Chlorine isotope geochemistry of Icelandic thermal fluids: Implications for geothermal system behavior at divergent plate boundaries. Earth and Planetary Science Letters 449, 69-78.

Takehara, M., Horie, K., HokadA, T., Kiyokawa, S. (2018) New insight into disturbance of $\mathrm{U}-\mathrm{Pb}$ and trace-element systems in hydrothermally altered zircon via SHRIMP analyses of zircon from the Duluth Gabbro. Chemical Geology 484, 168-178.

Trail, D., Mojzsis, S.J., Harrison, T.M., SCHMitT, A.K., WATSON, E.B., YouNG, E.D. (2007) Constraints on Hadean zircon protoliths from oxygen isotopes, Ti-thermometry, and rare earth elements. Geochemistry, Geophysics, Geosystems 8, 1-22.

Trail, D., WATSON, E.B., TAILby, N.D. (2011) The oxidation state of Hadean magmas and implications for early Earth's atmosphere. Nature 480, 79-82.

Trail. D., Cherniak, D.J., Watson, E.B., Harrison, T.M., Weiss, B.P., SzUMILA., I. (2016) Li zoning in zircon as a potential geospeedometer and peak temperature indicator. Contributions to Mineralogy and Petrology 171, 25-40

WATSON, E.B., HARRISON, T.M. (2005) Zircon thermometer reveals minimum melting conditions on earliest Earth. Science 308, 841-844. 